\title{
Food as preventive medicine
}

\section{Editorial}

Cardiovascular diseases (CVDs) are one of the leading causes of death around the world. According to world health organization (WHO) report, in 2012, around 17.5 million people have died with CVDs, representing $31 \%$ of all global deaths. CVDs are projected to remain the single leading cause of death and it is estimated that the death number will increase to reach 23.3 million by $2030 .{ }^{1}$ Intravascular thrombosis is one of the major reasons of CVDs including acute myocardial infarction, ischemic heart disease, and high blood pressure. ${ }^{2}$ Fibrin is the major insoluble protein component of blood clot/thrombus, which is formed from fibrinogen by the action of thrombin (EC 3.4.21.5). Under normal healthy conditions, fibrin clot formation and fibrinolysis are well balanced, while in unbalanced state, clots are not lysed which result in thrombosis. ${ }^{2}$ Formation of thrombus is a very complicated physiological process which involves many factors. Fibrinolytic enzymes can degrade fibrin clot into fibrin degradation products. Based on their mode of action fibrinolytic enzymes can be grouped as plasminogen activators (indirect type), where they activate plasminogen into plasmin; whereas the other group plasmin like proteins (direct type) can act directly on thrombus or fibrin clot. ${ }^{3,4}$ Anticoagulants such as various inhibitors of coagulation process and thrombolytic agents are used for the prevention and treatment of thrombosis. ${ }^{5}$ Clinically, most of the thrombolytic agents used are tissue-type plasminogen activator (t-PA), a urokinase-type plasminogen activator (u-PA), and streptokinase from bacterial origin. ${ }^{2}$ Although they are widely applied, these thrombolytic agents have undesirable side effects such as excessive bleeding caused by proteolytic degradation of other blood proteins, low specificity towards fibrin and are relatively expensive. ${ }^{4}$ Therefore, researchers are actively searching for novel thrombolytic agents from different sources. Fibrinolytic enzymes are studied from different sources such as microorganisms, ${ }^{3}$ insects, ${ }^{6}$ polychaetes, ${ }^{7}$ earthworms, ${ }^{8}$ snake venoms, ${ }^{9}$ fermented foods ${ }^{5}$ and mushrooms. ${ }^{10}$

Nattokinase (NK) was first discovered from Japanese traditional fermented food "natto"11" and its oral administration enhanced fibrinolysis in Canine plasma. ${ }^{12}$ These results imply the possibility of consuming fermented foods to prevent cardiovascular diseases and laid the foundation to search for fibrinolytic enzymes from other foods and food grade microorganisms. Several potential fibrinolytic enzymes have been purified and characterized from various Asian fermented foods such as Chinese douche, ${ }^{13}$ Korean fermented soybean sauce, Chungkook-Jang ${ }^{14}$ and deonjang, ${ }^{15}$ Korean fermented sea-food, Jeot-gal, ${ }^{16}$ Korean salt-fermented fish-food, Anchovyjoet, ${ }^{17}$ fermented shrimp paste ${ }^{18}$ and Indonesian fermented soybean, Tempeh. ${ }^{19}$ Fibrinolytic enzymes present in these traditional foods are mostly produced by Bacillus sp. Mushrooms are commonly consumed as food and also used in traditional oriental medicine. In recent years, mushrooms have become an attractive source of various bioactive compounds. Therefore, fibrinolytic enzymes from nontoxic mushrooms received wide research attention for thrombolytic therapy. Several fibrinolytic enzymes have been reported from various mushrooms. ${ }^{10}$

Researchers around the world are actively working on health benefits of foods by identifying the functional constituents, their
Volume I Issue 2 - 2015

\section{Narasimha Kumar Kopparapu \\ College of Food and Biological Engineering, Qiqihar University, China}

Correspondence: Narasimha Kumar Kopparapu, College of Food and Biological Engineering, Qiqihar University, Qiqihar-161006, Heilongjiang, China, Tel +86-18846205068, Email bionarsi@gmail.com, bionarsi@yahoo.com

Received: July 9, 2015 | Published: August 13,2015

biochemical structures and mechanisms. Beyond their dietary essential, understanding the health benefits of food in prevention and treatment of chronic diseases is a promising research. ${ }^{5}$ Fibrinolytic enzymes derived from food grade microorganisms have great potential to be developed as functional food additives and drugs to prevent/cure thrombotic diseases. ${ }^{2}$

\section{Acknowledgements}

None.

\section{Conflict of interest}

The author declares no conflict of interest.

\section{References}

1. World health organization. Cardiovascular diseases (CVDS). WHO; 2015.

2. Choi D, Cha WS, Park N, et al. Purification and characterization of a novel fibrinolytic enzyme from fruiting bodies of Korean Cordyceps militaris. Bioresour Technol. 2011;102(3):3279-3285.

3. Peng Y, Yang X, Zhang Y. Microbial fibrinolytic enzymes: an overview of source, production, properties, and thrombolytic activity in vivo. Appl Microbiol Biotechnol. 2005;69(2):126-132.

4. Wu B, Wu L, Chen D, et al. Purification and characterization of a novel fibrinolytic protease from Fusarium sp. CPCC480097. J Ind Microbiol Biotechnol. 2009;36(3):451-459.

5. Mine $\mathrm{Y}$, Wong AH, Jiang B. Fibrinolytic enzymes in Asian traditional fermented foods. Food Res Int. 2005;38(3):243-250.

6. Ahn MY, Hahn BS, Ryu KS, et al. Purification and characterization of a serine protease with fibrinolytic activity from the dung beetles, Catharsius molossus. Thromb Res. 2003;112(5-6):339-347.

7. Deng Z, Wang S, Li Q, et al. Purification and characterization of a novel fibrinolytic enzyme from the polychaete, Neanthes japonica (Iznka). Bioresour Technol. 2010;101(6):1954-1960.

8. Wang F, Wang C, Li M, et al. Crystal structure of earthworm fibrinolytic enzyme component B: a novel, glycosylated two chained trypsin. $J \mathrm{Mol}$ Biol. 2005;348(3):671-685.

9. De-Simone SG, Correa-Netto C, Antunes OA, et al. Biochemical and molecular modeling analysis of the ability of two p-aminobenzamidinebased sorbents to selectively purify serine proteases (fibrinogenases) from snake venoms. J Chromatogr. 2005;822(1-2):1-9. 
10. Lu CL, Chen SN. Fibrinolytic enzymes from medicinal mushrooms. In Faraggi E editor. Protein Structure. China: Intech; 2012. p. 337-363.

11. Sumi H, Hamada H, Nakanishi K, et al. Enhancement of the fibrinolytic activity in plasma by oral administration of NK. Acta Haematol. 1990;84(3):139-143.

12. Sumi H, Hamada H, Tsushima $H$, et al. A novel fibrinolytic enzyme (Nattokinase) in the vegetable cheese Natto, a typical and popular soybean food in the Japanese diet. Experientia. 1987;43(10):1110-1111.

13. Peng Y, Huang Q, Zhang RH, et al. Purification and characterization of a fibrinolytic enzyme produced by Bacillus amyloliquefaciens DC-4 screened from douchi, a traditional Chinese soybean food. Comp Biochem Physiol B Biochem Mol Biol. 2003;134(1):45-52.

14. Kim W, Choi K, Kim Y, et al. Purification and characterization of a fibrinolytic enzyme produced from Bacillus sp. strain CK 11-4 screened from Chungkook-Jang. Appl Environ Microbiol. 1996;62(7):2482-2488.

15. Kim JM, Suh HJ, Ahn SW, et al. Fibrinolytic enzyme production by Bacillus subtilis KH-4 isolated from Deonjang. Nutraceuticals \& Food. 2002;7(4):417-420.
16. Hwang KJ, Choi KH, Kim MJ, et al. Purification and characterization of a new fibrinolytic enzyme of Bacillus licheniformis KJ-31, isolated from Korean traditional Jeot-gal. J Microbiol Biotechnol. 2007;17(9):14691476.

17. Choi NS, Song JJ, Chung DM, et al. Purification and characterization of a novel thermoacid-stable fibrinolytic enzyme from Staphylococcus sp. strain AJ isolated from Korean salt-fermented Anchovy-joet. $J$ Ind Microbiol Biotechnol. 2009;36(3):417-426.

18. Hua Y, Jiang B, Mine Y, Mu W. Purification and characterization of a novel fibrinolytic enzyme from Bacillus sp. nov. SK006 isolated from an Asian traditional fermented shrimp paste. J Agr Food Chem. 2008;56(4):14511457.

19. Kim SB, Lee DW, Cheigh CI, et al. Purification and characterization of a fibrinolytic subtilisin-like protease of Bacillus subtilis TP-6 from an Indonesian fermented soybean, Tempeh. J Ind Microbiol Biotechnol. 2006;33(6):436-444. 